\title{
Influence of irrigation and nitrogen fertilization on grain yield and some baking quality characteristics of spring wheat
}

\author{
PaAvo Elonen ${ }^{1}$ ) and Sirkka-Lissa Rinne \\ Agricultural Research Centre, Department of Soil Science, 01301 Vantaa \\ Hilkкa Suomela ${ }^{2}$ ) \\ University of Helsinki, Department of Plant Husbandry, $00710 \mathrm{Helsinki}$
}

\begin{abstract}
In the years 1967-70 twelve irrigation experiments of spring wheat were carried out in southern Finland $\left(60-62^{\circ} \mathrm{N}, 22-26^{\circ} \mathrm{E}\right)$. Sprinkler irrigation $(2 \times$ $30 \mathrm{~mm}$ ) increased the grain yields on an average by $1240 \pm 470 \mathrm{~kg} / \mathrm{ha}$ (from 2740 to 3980 $\mathrm{kg}$ ) or $45 \pm 17 \%$. The increases in yield were significant on clay soils (9 trials) and loam ( 1 trial) but insignificant on finesand $(1$ trial) and mould $(1$ trial). Additional nitrogen fertilization (from 76 to $143 \mathrm{~kg} / \mathrm{ha} \mathrm{N}$ ) increased the grain yields on an average by $350 \pm$ $200 \mathrm{~kg} / \mathrm{ha}$ or $11 \pm 6 \%$.

The ripening of wheat was significantly promoted by irrigation in one year but slightly retarded in three years. Nitrogen fertilization slightly retarded ripening every yearThe falling number of grains tended to be slightly improved by irrigation (from 285 to 321 , on an average), but in most trials irrigation and nitrogen fertilization had no significant influence on the falling number.

Irrigation decreased the crude protein content of grains in all trials, on an average by $2.2 \pm 0.7 \%$-units (from 16.3 to $14.1 \%$ ). This unfavourable effect was, however, avoided with additional nitrogen which increased the protein content by $1.9 \pm 0.4 \%$-units (from 14.3 to $16.2 \%$ ).

The effects of irrigation and nitrogen fertilization on those characteristics of wheat that are correlated with protein, were similar to the effects on the protein content. Thus, irrigation decreased the zeleny value (from 64 to $53 \mathrm{ml}$ ), cold viscosity (from 214 to 114 seconds), water absorption (from 66.5 to $64.9 \%$ ) and the valorimeter value (from 68 to $60)$, while these characteristics wcre improved by nitrogen fertilization.

Irrigation did not decrease the Pelshenke value but increased significantly the ratio of the Pelshenke value/protein content (from 5.1 to 6.1). This indicates that the quality of protein was improved by irrigation, while the effect of nitrogen fertilization was the reverse. In fact, irrigation and additional nitrogen fertilization affected the quantity and quality of protein and the baking quality characteristics of wheat in opposite directions but the quantity of grain yield in the same direction. With these two methods combined it was possible to produce $60 \%$ higher grain yields without any noteworthy changes in the baking quality characteristics of spring wheat.
\end{abstract}

1) Earlier address: University of Helsinki, Department of Agricultural Chemistry.

2) Earlier address: Research Laboratory of Grain Research Committee and State Granary. 
Many factors affect the baking quality of spring wheat. According to HLYNKA (1964) two basic groups of factors are involved: first, the quality factors which exist in the wheat itself and are a result of the genetic components of the variety plus the changes brought about by growing conditions, i.e. fertilization, weather, soil fertility, and second, the quality factors which may change during the process of converting the wheat into flour.

It has been established that the major factor accounting for the variation in loaf volume is the gluten protein content. The relation between loaf volume and protein content is linear but the regression coefficient differs widely with different varieties (FAJERSSON 1974). Gluten is formed of two proteins: gliadin and glutenin, of which the gliadin fraction has been shown to control the loaf volume and to vary in accordance with the breadmaking potential of the flour (Hoseney et al. 1969). The factor responsible for the mixing time and the dough development is the glutenin fraction. Pomeranz (1974) believes that the key to breadmaking strength is to be found in the gliadin fraction and its interaction with other flour components, especially glycolipids. This interaction depends on the composition of the gliadin proteins, which is genetically controlled. The synthesis of gliadin occurs at a later stage of ripening than that of glutenin (Bilinski and McConnell 1958). Therefore it may be assumed that cultivation measures that influence the ripening of wheat also affect the quality of the gluten.

It has been established that in Finland, as a consequence of sprinkler irrigation, the protein content of grain decreases while an application of nitrogen fertilizer before irrigation can eliminate this unfavourable effect (ELONEN et al. 1972, ELONEN and KARA 1972). A part of the present results have been treated with a view to the effect of irrigation and nitrogen fertilization on the biological quality of protein (ELONEN et al. 1972). It appears that even if the irrigation lowers the protein content of wheat, the amino-acid composition is improved owing to the increased proportion of lysine.

For determining the baking quality of wheat, several physical and chemical methods have been developed. The present paper reports results of the effects of irrigation and nitrogen fertilization on the baking quality characteristics.

\section{Materials and methods}

Experimental fields (Table 1). In the years 1967-70 twelve field experiments at seven sites in southern Finland $\left(60-62^{\circ} \mathrm{N}, 22-26^{\circ} \mathrm{E}\right)$ were carried out by the Department of Agricultural Chemistry, Helsinki University and the Finnish Research Institute of Agricultural Engineering. The soil was clay soil in nine trials, in the other fields the soil was loam, finesand and mould. The experimental crops consisted of three different spring wheat varieties: Svenno, Ruso and Norröna.

F e r tiliz a tion (Table 1). A basal dressing, either a compound fertilizer (Trials 1-2, 4-9 and 11-12), ammoniated PK-fertilizer (Trial 3) or ammoniated PK + ammonium nitrate limestone (Trial 10), was placed in rows at a depth of $8 \mathrm{~cm}$. It contained, on an average over four years, $76 \mathrm{~kg} \mathrm{~N}, 50 \mathrm{~kg}$ $\mathrm{P}$ and $73 \mathrm{~kg} \mathrm{~K}$ per hectare. Additional nitrogen on the $\mathrm{N}_{2}$-plots, an average of 
Table 1. Soil, wheat variety, fertilization, and irrigation of the experimental fields.

\begin{tabular}{|c|c|c|c|c|c|c|c|c|c|c|}
\hline \multicolumn{2}{|c|}{ Trial } & \multirow{2}{*}{$\begin{array}{c}\left.\text { Farm }^{1}\right) \\
\text { No. }\end{array}$} & \multirow{2}{*}{ Soil } & \multirow{2}{*}{$\begin{array}{l}\text { Wheat } \\
\text { variety }\end{array}$} & \multicolumn{4}{|c|}{$\begin{array}{l}\text { Fertilization } \\
\mathrm{kg} \text { per hectare }\end{array}$} & \multicolumn{2}{|c|}{$\begin{array}{l}\text { Dates of } \\
\text { irrigation }\end{array}$} \\
\hline No. & Year & & & & $\mathrm{N}_{1}$ & $\mathrm{~N}_{2}$ & $\mathrm{P}$ & $\mathrm{K}$ & $30 \mathrm{~mm}$ & $30 \mathrm{~mm}$ \\
\hline 1 & 1967 & 1 & Silty clay & Svenno & 60 & 122 & 43 & 56 & 15.6. & 21.6. \\
\hline 2 & 1968 & 1 & Silty clay & Svenno & 75 & 137 & 44 & 62 & 9.6. & 17. 6. \\
\hline 3 & 1969 & 1 & Silty clay & Ruso & 16 & 136 & 59 & 100 & 9. 6. & 17. 6. \\
\hline 4 & & 2 &,$\quad$ & Norröna & 98 & 158 & 57 & 81 & 10.6. & 25.6. \\
\hline 5 & & 3 & Loamy clay & Svenno & 90 & 150 & 52 & 75 & 16. 6. & 25. 6. \\
\hline 6 & & 4 & , & Svenno & 120 & 180 & 52 & - & 10.6. & 18. 6. \\
\hline 7 & & 5 & Finesand & Norröna & 52 & 112 & 40 & 66 & 13. 6. & 24.6. \\
\hline 8 & & 6 & Loam & Ruso & 68 & 128 & 39 & 56 & 11. 6. & 24.6. \\
\hline 9 & & 7 & Loamy clay & Ruso & 105 & 165 & 61 & 87 & 12. 6. & 23. 6. \\
\hline 10 & 1970 & 1 & Silty clay. & Ruso & 92 & 167 & 63 & 106 & 9.6. & 16. 6. \\
\hline 11 & & 2 & Mould & Ruso & 140 & - & 61 & - & 11. 6. & 23. 6 . \\
\hline 12 & & 3 & Loamy clay & Svenno & 120 & - & 26 & 50 & 15.6. & 23. 6. \\
\hline
\end{tabular}

1) Farms: $1=$ Pakankylä, $2=$ Lampola, $3=$ Uoti, $4=$ Kara, $5=$ Iso-Hiisi, $6=$ Ojala, $7=$ Tiuttu

$67 \mathrm{~kg} / \mathrm{ha}$, was applied either as surface dressing for the shoots as calcium nitrate (Trials $1-2$ ) or as ammonium nitrate limestone (Trials $4-9$ ), or the additional nitrogen was placed in connection with sowing as ammonium nitrate limestone (Trials 3 and 10).

I r rig a tion (Table 1). The irrigation was performed by a slow rotary sprinkler twice in June in between sprouting and ear emergence, at both times with $30 \mathrm{~mm}$ of water. All treatments were in four replicates except those of Trials 2, 6, 7, 11 and 12 which had three replicates.

$\mathrm{W}$ e a $\mathrm{th}$ e r (Table 2). The growing seasons were abnormally dry except the month of August in the years 1967-68 and July in 1970. The mean temperatures did not markedly differ from those of normal seasons.

Ripening and harvesting (Table 3 ). The harvest of the experimental plots was carried out with a combine-harvester as soon as the wheat had reached a stage of yellow ripeness. Consequently the moisture degree of the grains can be considered as a measure of the ripening. In 1967, 1969 and 1970 the irrigated wheat ripened later than the non-irrigated one. On the other hand, in 1968 irrigation greatly promoted the ripening. In that year the shooting of the wheat was poor and rains in July caused detrimental late tillering and uneven ripening. In the irrigated wheat stand, which was more vigorous and dense than the non-irrigated stand, there was no late tillering. Additional nitrogen caused almost without exception a slight retardation in ripening.

Analyses of $\mathrm{grain}$ and flour. Analyses of baking quality characteristics were conducted in the Laboratory of the Grain Research Committee. For a determination of the crude protein content in the grain, the 


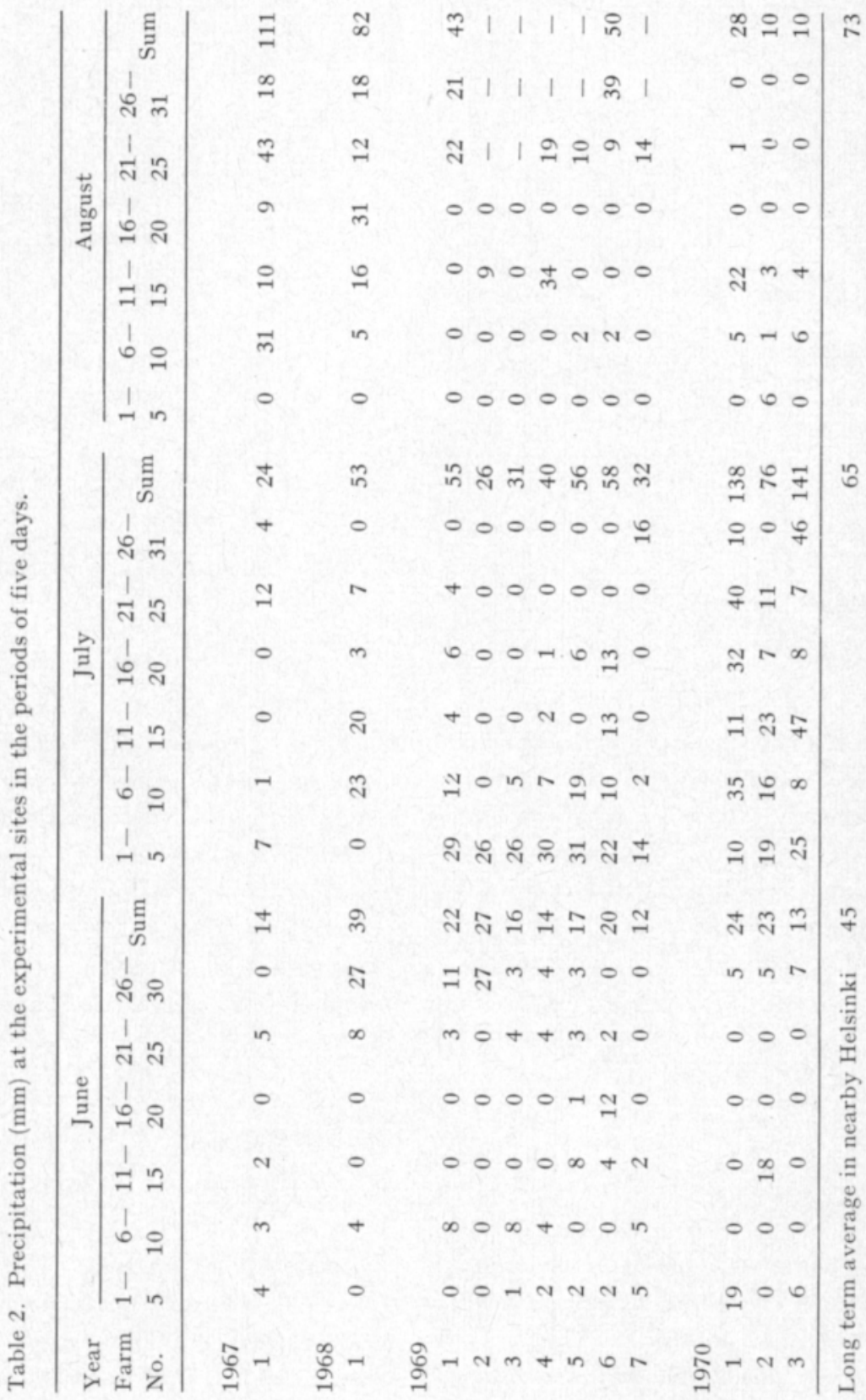


Table 3. Moisture of grains at the harvest, $\%$.

\begin{tabular}{|c|c|c|c|c|c|c|c|c|}
\hline \multirow{2}{*}{ Year } & \multirow{2}{*}{$\begin{array}{c}\text { Farm } \\
\text { No. }\end{array}$} & \multirow{2}{*}{$\begin{array}{c}\text { Date } \\
\text { of har- } \\
\text { vest }\end{array}$} & \multicolumn{2}{|c|}{ Not irrigated } & \multicolumn{2}{|c|}{ Irrigated } & \multirow{2}{*}{$\frac{\text { Irrigation }}{\text { effect }}$} & \multirow{2}{*}{$\frac{\mathrm{N} \text {-fertilization }}{\text { effect }}$} \\
\hline & & & $\mathrm{N}_{1}$ & $\mathrm{~N}_{2}$ & $\mathrm{~N}_{1}$ & $\mathrm{~N}_{2}$ & & \\
\hline 1967 & 1 & 30.8 . & 25.4 & 26.0 & 26.6 & 28.3 & +1.8 & $+1.2^{*}$ \\
\hline 1968 & 1 & 5. 9 . & 27.9 & 32.1 & 21.9 & 25.1 & $-6.5 * *$ & $+3.7 * *$ \\
\hline \multirow[t]{8}{*}{1969} & 1 & 20.8 . & 15.1 & 18.0 & 18.4 & 26.9 & $+6.1 * *$ & $+5.7 * *$ \\
\hline & 2 & 24.8 . & 27.4 & 31.8 & 31.7 & 34.8 & $+3.7^{* * *}$ & $+3.8 * * *$ \\
\hline & 3 & 1. 9 . & 31.7 & 31.8 & 31.9 & 33.0 & +0.7 & +0.6 \\
\hline & 4 & 25. 8. & 26.1 & 26.4 & 26.9 & 27.4 & +0.9 & +0.4 \\
\hline & 5 & 26. 8. & 29.5 & 30.2 & 31.9 & 35.0 & $+3.6^{*}$ & $+1.9^{*}$ \\
\hline & 6 & 28. 8. & 31.2 & 31.5 & 34.5 & 35.2 & $+3.5^{* * *}$ & +0.5 \\
\hline & 7 & 29. 8. & 23.4 & 23.4 & 27.3 & 27.6 & $+4.1 * * *$ & +0.2 \\
\hline & mean & & 26.3 & 27.5 & 28.9 & 31.4 & $+3.3^{* * *}$ & $+1.9 * *$ \\
\hline \multirow[t]{3}{*}{1970} & 1 & 25. 8. & 18.3 & 19.2 & 19.3 & 21.2 & $+1.5^{*}$ & +1.4 \\
\hline & 2 & 31. 8 . & 23.2 & & 28.8 & & $+5.6^{*}$ & - \\
\hline & 3 & 7. 9. & 26.3 & & 26.7 & & +0.4 & - \\
\hline \multicolumn{3}{|c|}{4 years, $\left.^{\text {aver. }}{ }^{1}\right)$} & 24.5 & 26.2 & 24.2 & 26.5 & \pm 0 & $+2.0^{* *}$ \\
\hline
\end{tabular}

1) in 1970 only Farm 1 included

total nitrogen was analysed according to the Kjeldahl procedure and multiplied by 5.7. Cold viscosity was analysed with a method proposed by Suomela $(1969,1970)$. All other analyses were done according to the Standard Methoden (1971). For analyses of the valorimeter value and the water absorption of flour, the grains were ground in a Quatromat Junior mill to give flour of 60 per cent extraction.

$\mathrm{St}$ at istical significance. The significance of the experimental results, according to the t-test, has been reported at three confidence levels: at $95 \%\left({ }^{*}\right), 99 \%\left({ }^{* *}\right)$ and $99.9 \%\left({ }^{* * *}\right)$ levels.

\section{Results}

Grain yield (Table 4)

Irrigation increased the grain yields significantly every year. An average increase in the whole 4-year material was $1240 \pm 470 \mathrm{~kg}$ per hectare (from 2740 to $3980 \mathrm{~kg}$ ) or $45 \pm 17 \%$. The increase was significant on ten sites where the soil was clay or loam, while on two sites, where the soil was finesand or mould, the effect of irrigation was negligible.

Additional nitrogen fertilization increased the grain yields on an average by $350 \pm 200 \mathrm{~kg} / \mathrm{ha}$ or $11 \pm 6 \%$. The increases were significant in only five trials. Nitrogen was more effective on irrigated plots $\left(+540^{* * *} \mathrm{~kg} / \mathrm{ha}\right)$ than without irrigation $\left(+160^{*} \mathrm{~kg} / \mathrm{ha}\right)$. 
Table 4. Grain yields, $\mathrm{kg} / \mathrm{ha}$.

\begin{tabular}{|c|c|c|c|c|c|c|c|}
\hline \multirow{2}{*}{ Year } & \multirow{2}{*}{$\begin{array}{c}\text { Farm } \\
\text { No. }\end{array}$} & \multicolumn{2}{|c|}{ Not irrigated } & \multicolumn{2}{|c|}{ Irrigated } & \multirow{2}{*}{$\frac{\text { Irrigation }}{\text { effect }}$} & \multirow{2}{*}{$\frac{\mathrm{N} \text {-fertilization }}{\text { effect }}$} \\
\hline & & $\mathrm{N}_{1}$ & $\mathrm{~N}_{2}$ & $\mathrm{~N}_{1}$ & $\mathrm{~N}_{2}$ & & \\
\hline 1967 & 1 & 2100 & 2170 & 3420 & 4200 & $+1680^{* * *}$ & $+430^{*}$ \\
\hline 1968 & 1 & 2280 & 2380 & 3870 & 4340 & $+1880^{* * *}$ & +290 \\
\hline \multirow[t]{8}{*}{1969} & 1 & 2260 & 3610 & 2950 & 5360 & $+1220^{* *}$ & $+1880^{* * *}$ \\
\hline & 2 & 3940 & 3840 & 4620 & 4740 & $+790^{* * *}$ & $+\quad 10$ \\
\hline & 3 & 2930 & 3120 & 3420 & 3950 & $+660 * *$ & $+360 * *$ \\
\hline & 4 & 1320 & 1400 & 2640 & 2470 & $+1200^{* *}$ & -50 \\
\hline & 5 & 3090 & 3180 & 3620 & 3360 & +360 & -90 \\
\hline & 6 & 2290 & 2430 & 2510 & 2770 & $+280^{*}$ & $+200^{*}$ \\
\hline & 7 & 2090 & 1960 & 3130 & 3060 & $+1070^{* *}$ & -100 \\
\hline & mean & 2560 & 2790 & 3270 & 3670 & $+800 * * *$ & +320 \\
\hline \multirow[t]{3}{*}{1970} & 1 & 3680 & 3950 & 4280 & 4790 & $+720^{* *}$ & $+390 * * *$ \\
\hline & 2 & 4360 & & 4380 & & +20 & - \\
\hline & 3 & 3560 & & 4570 & & $+1010^{*}$ & - \\
\hline \multicolumn{2}{|c|}{4 years, aver. ${ }^{1}$ ) } & 2660 & 2820 & 3710 & 4250 & $+1240^{* * * *}$ & $+350^{* *}$ \\
\hline
\end{tabular}

1) in 1970 only Farm 1 included

Table 5. Crude protein content of grains, $\%$ of dry matter.

\begin{tabular}{|c|c|c|c|c|c|c|c|}
\hline \multirow{2}{*}{ Year } & \multirow{2}{*}{$\begin{array}{c}\text { Farm } \\
\text { No. }\end{array}$} & \multicolumn{2}{|c|}{ Not irrigated } & \multicolumn{2}{|c|}{ Irrigated } & \multirow{2}{*}{$\frac{\text { Irrigation }}{\text { effect }}$} & \multirow{2}{*}{$\frac{\mathrm{N} \text {-fertilization }}{\text { effect }}$} \\
\hline & & $\mathrm{N}_{1}$ & $\mathrm{~N}_{2}$ & $\mathrm{~N}_{1}$ & $\mathrm{~N}_{2}$ & & \\
\hline 1967 & 1 & 14.5 & 16.1 & 12.4 & 15.0 & $-1.6^{* *}$ & $+2.1 * * *$ \\
\hline 1968 & 1 & 16.6 & 18.3 & 13.2 & 14.8 & $-3.4^{* * *}$ & $+1.7 * *$ \\
\hline \multirow[t]{8}{*}{1969} & 1 & 13.1 & 17.5 & 12.2 & 14.7 & $-1.9 * *$ & $+3.5 * * *$ \\
\hline & 2 & 11.4 & 13.4 & 9.9 & 11.3 & $-1.8^{* * *}$ & $+1.7 * * *$ \\
\hline & 3 & 15.1 & 15.9 & 13.7 & 14.5 & $-1.4 * *$ & $+0.8^{*}$ \\
\hline & 4 & 19.3 & 19.6 & 17.0 & 17.7 & $-2.1 * * *$ & +0.5 \\
\hline & 5 & 13.4 & 15.5 & 11.3 & 12.5 & $-2.6^{* * *}$ & $+1.7 * *$ \\
\hline & 6 & 13.9 & 16.1 & 12.2 & 14.5 & $-1.7 * * *$ & $+2.3 * * *$ \\
\hline & 7 & 17.3 & 17.8 & 15.7 & 16.6 & $-1.4^{* *}$ & +0.7 \\
\hline & mean & 14.8 & 16.5 & 13.1 & 14.5 & $-1.8^{* * *}$ & $+1.6 * * *$ \\
\hline \multirow[t]{3}{*}{1970} & 1 & 16.0 & 17.7 & 13.5 & 16.1 & $-2.1 * * *$ & $+2.2^{* * *}$ \\
\hline & 2 & 13.2 & & 12.3 & & -0.9 & - \\
\hline & 3 & 15.9 & & 13.9 & & $-2.0^{*}$ & - \\
\hline \multicolumn{2}{|c|}{4 years, aver, ${ }^{1}$ ) } & 15.5 & 17.2 & 13.1 & 15.1 & $-2.2 * * *$ & $+1.9 * * *$ \\
\hline
\end{tabular}

1) In 1970 only Farm 1 included 
Table 6. Falling number, seconds.

\begin{tabular}{|c|c|c|c|c|c|c|c|}
\hline \multirow{2}{*}{ Year } & \multirow{2}{*}{$\begin{array}{c}\text { Farm } \\
\text { No. }\end{array}$} & \multicolumn{2}{|c|}{ Not irrigated } & \multicolumn{2}{|c|}{ Irrigated } & \multirow{2}{*}{$\frac{\text { Irrigation }}{\text { effect }}$} & \multirow{2}{*}{$\frac{\mathrm{N} \text {-fertilization }}{\text { effect }}$} \\
\hline & & $\mathrm{N}_{1}$ & $\mathrm{~N}_{2}$ & $\mathrm{~N}_{1}$ & $\mathrm{~N}_{2}$ & & \\
\hline 1967 & 1 & 277 & 290 & 314 & 358 & $+53^{*}$ & $+29^{*}$ \\
\hline 1968 & 1 & 229 & 185 & 239 & 269 & +47 & -7 \\
\hline \multirow[t]{8}{*}{1969} & 1 & 391 & 402 & 392 & 400 & -1 & $+10^{*}$ \\
\hline & 2 & 384 & 390 & 385 & 356 & -17 & -12 \\
\hline & 3 & 237 & 220 & 243 & 243 & +15 & -9 \\
\hline & 4 & 338 & 352 & 366 & 373 & +25 & +11 \\
\hline & 5 & 373 & 350 & 342 & 281 & -50 & -42 \\
\hline & 6 & 305 & 283 & 248 & 224 & $-58^{*}$ & -23 \\
\hline & 7 & 205 & 165 & 254 & 241 & $+63 * *$ & -27 \\
\hline & mean & 319 & 309 & 319 & 303 & -3 & $-13^{*}$ \\
\hline \multirow[t]{3}{*}{1970} & 1 & 360 & 308 & 398 & 363 & +47 & -44 \\
\hline & 2 & 388 & & 385 & & -3 & - \\
\hline & 3 & 351 & & 378 & & +27 & - \\
\hline \multicolumn{2}{|c|}{4 years, aver. ${ }^{1}$ ) } & 296 & 273 & 318 & 323 & $+36^{*}$ & -9 \\
\hline
\end{tabular}

1) In 1970 only Farm 1 included

Protein content of grains (Table 5)

The protein content of wheat was in most trials fairly high. This was probably due to the relatively abundant nitrogen fertilization and favourable weather conditions.

Irrigation decreased the crude protein content of the grains in all trials, on an average by $2.2 \pm 0.7 \%$-units (from 16.3 to $14.1 \%$ ). This decrease was significant in all trials except in 1970 on Farm No. 2, where the soil was mould and the effect of irrigation on the yield was likewise insignificant (Tables 1 and 4).

This unfavourable decrease in the protein content of grains, caused by irrigation, could be almost fully compensated by additional fertilizer nitrogen, at $67 \mathrm{~kg}$ per hectare, on an average (Table 1). This amount of nitrogen increased the protein content of the grains on an average by $1.9 \pm 0.4 \%$-units (from 14.3 to $16.2 \%$ ). The increase in the protein content was significant in all but two trials.

Falling number (Table 6)

The falling number, which correlates with the alpha-amylase activity, is a measure of the starch quality and the resistance to sprouting damage, which play an important role in the baking quality (FAJERSSON 1974).

In the experimental years the harvest was generally favoured by good weather conditions which resulted in high falling numbers in every trial. Irrigation tended slightly to improve the falling number (from 285 to 321 , on an average), 
Table 7. Zeleny-values, $\mathrm{ml}$.

\begin{tabular}{|c|c|c|c|c|c|c|c|}
\hline \multirow{2}{*}{ Year } & \multirow{2}{*}{$\begin{array}{c}\text { Farm } \\
\text { No. }\end{array}$} & \multicolumn{2}{|c|}{ Not irrigated } & \multicolumn{2}{|c|}{ Irrigated } & \multirow{2}{*}{$\frac{\text { Irrigation }}{\text { effect }}$} & \multirow{2}{*}{$\frac{\mathrm{N} \text {-fertilization }}{\text { effect }}$} \\
\hline & & $\mathrm{N}_{1}$ & $\mathrm{~N}_{2}$ & $\mathrm{~N}_{1}$ & $\mathrm{~N}_{2}$ & & \\
\hline 1967 & 1 & 64 & 70 & 44 & 63 & $-14^{*}$ & $+13^{* *}$ \\
\hline 1968 & 1 & 69 & 72 & 52 & 62 & $-14^{*}$ & $+7 *$ \\
\hline \multirow[t]{8}{*}{1969} & 1 & 33 & 56 & 30 & 45 & $-7^{*}$ & $+19 * * *$ \\
\hline & 2 & 27 & 34 & 21 & 26 & $-7 * * *$ & $+6 * *$ \\
\hline & 3 & 67 & 70 & 53 & 59 & $-13 * * *$ & $+5^{*}$ \\
\hline & 4 & 72 & 72 & 71 & 71 & $-1 *$ & \pm 0 \\
\hline & 5 & 35 & 48 & 24 & 31 & $-14 * *$ & $+10^{* *}$ \\
\hline & 6 & 41 & 56 & 31 & 48 & $-9 * * *$ & $+16^{* * *}$ \\
\hline & 7 & 69 & 69 & 62 & 66 & $-5^{*}$ & +2 \\
\hline & mean & 49 & 58 & 42 & 49 & $-8^{* * *}$ & $+8^{* * *}$ \\
\hline \multirow[t]{3}{*}{1970} & 1 & 58 & 66 & 44 & 63 & $-9 * *$ & $+14^{* * *}$ \\
\hline & 2 & 41 & & 33 & & $-8^{*}$ & - \\
\hline & 3 & 70 & & 57 & & $-13^{*}$ & - \\
\hline \multicolumn{2}{|c|}{4 years, aver. ${ }^{1}$ ) } & 60 & 67 & 46 & 59 & $-11 * *$ & $+10^{* *}$ \\
\hline
\end{tabular}

1) In 1970 only Farm 1 included

but in most trials irrigation had no significant influence. It is difficult to find any interaction between the effects of irrigation on ripening and on the falling number (Tables 3 and 6).

Like irrigation, nitrogen fertilization had no clear effect on the falling numbers in spite of the fact that it slightly retarded ripening in every trial.

\section{Zeleny value (Table 7)}

The zeleny test shows imbibitional properties to evaluate the breadmaking properties of flour. Because the Zeleny value is strongly influenced by the protein content, it was affected by irrigation and nitrogen fertilization in the same way as was the protein content: Irrigation reduced the Zeleny value significantly in every trial. The average reduction was $11 \pm 5 \mathrm{ml}$ (from 64 to 53). Additional nitrogen increased the Zeleny value on an average by $10 \pm 5 \mathrm{ml}$ (from 53 to 63 ). The increases were significant in other trials except the two where the effect of nitrogen on the protein content was also insignificant (Table 5).

\section{Cold viscosity (Table 8 )}

The cold viscosity of a coarse ground grain-water suspension is a measure of the quantity and quality of the protein (Suomela 1969, 1970). Variation in the cold viscosity between different years and farms was particularly pronounced. The differences between the experiments were partly due to the different varieties the cold viscosity of the Norröna being the poorest (Farms 2 and $\mathbf{5}$ in 1969). 
Irrigation decreased the cold viscosity in every trial, significantly in seven out of twelve cases. On the other hand, the effect of additional nitrogen on the cold viscosity was in most trials positive and significant in four experiments.

Table 8. Cold viscosity, seconds.

\begin{tabular}{|c|c|c|c|c|c|c|c|}
\hline \multirow{2}{*}{ Year } & \multirow{2}{*}{$\begin{array}{c}\text { Farm } \\
\text { No. }\end{array}$} & \multicolumn{2}{|c|}{ Not irrigated } & \multicolumn{2}{|c|}{ Irrigated } & \multirow{2}{*}{$\frac{\text { Irrigation }}{\text { effect }}$} & \multirow{2}{*}{$\frac{\mathrm{N} \text {-fertilization }}{\text { effect }}$} \\
\hline & & $\mathrm{N}_{1}$ & $\mathrm{~N}_{2}$ & $\mathrm{~N}_{1}$ & $\mathrm{~N}_{2}$ & & \\
\hline 1967 & 1 & 67 & 83 & 64 & 69 & $-9^{*}$ & $+11^{* *}$ \\
\hline 1968 & 1 & 295 & 461 & 81 & 127 & $-274^{*}$ & +106 \\
\hline \multirow[t]{8}{*}{1969} & 1 & 69 & 115 & 68 & 73 & -22 & +26 \\
\hline & 2 & 63 & 67 & 62 & 62 & $-3 * *$ & $+2 *$ \\
\hline & 3 & 94 & 93 & 76 & 73 & $-19^{*}$ & -2 \\
\hline & 4 & 168 & 89 & 108 & 82 & -34 & -53 \\
\hline & 5 & 64 & 78 & 62 & 63 & -9 & +8 \\
\hline & 6 & 87 & 151 & 67 & 109 & $-31^{*}$ & $+53^{*}$ \\
\hline & 7 & 205 & 222 & 138 & 217 & -36 & +48 \\
\hline & mean & 107 & 116 & 83 & 97 & $-22 * *$ & +12 \\
\hline \multirow[t]{3}{*}{1970} & 1 & 284 & 300 & 93 & 300 & $-96^{*}$ & $+112^{*}$ \\
\hline & 2 & 123 & & 91 & & -32 & - \\
\hline & 3 & 73 & & 67 & & $-6^{*}$ & - \\
\hline \multicolumn{2}{|c|}{4 years, aver. ${ }^{1}$ ) } & 188 & 240 & 80 & 148 & -100 & +60 \\
\hline
\end{tabular}

1) In 1970 only Farm 1 included

Water absorption (Table 9)

The water absorption represents the amount of water needed for an optimum consistency of 500 Brabender units (BU). It is reported in percentages of flour weight. Absorption increases as the protein increases and the gluten quality improves.

Irrigation decreased the water absorption on an average by $1.7 \pm 0.9 \%$ units (from 66.5 to $64.9 \%$ ). The negative effect was significant in five trials. Nitrogen fertilization had a reversed effect: it improved the water absorption of flour on an average by $0.8 \pm 0.4 \%$-units. The effect was similar in all trials but significantly positive in only three cases.

Valorimeter value (Table 10)

Farinograms provide information on optimum mixing time and dough stability. The valorimeter value expresses various characteristics of a farinogram as a single score. Developing time and stability of dough depend on the quantity as well as the quality of the protein.

Irrigation significantly decreased the valorimeter value in six trials, and in the other trials the effect was in the same direction. On an average the re- 
Table 9. Water absorption, \%.

\begin{tabular}{|c|c|c|c|c|c|c|c|}
\hline \multirow{2}{*}{ Year } & \multirow{2}{*}{$\begin{array}{c}\text { Farm } \\
\text { No. }\end{array}$} & \multicolumn{2}{|c|}{ Not irrigated } & \multicolumn{2}{|c|}{ Irrigated } & \multirow{2}{*}{$\frac{\text { Irrigation }}{\text { effect }}$} & \multirow{2}{*}{$\frac{\mathrm{N} \text {-fertilization }}{\text { effect }}$} \\
\hline & & $\mathrm{N}_{1}$ & $\mathrm{~N}_{2}$ & $\mathrm{~N}_{1}$ & $\mathrm{~N}_{2}$ & & \\
\hline 1967 & 1 & 60.6 & 62.1 & 60.5 & 61.0 & -0.6 & $+1.0^{*}$ \\
\hline 1968 & 1 & 66.8 & 67.7 & 63.7 & 64.7 & $-3.1^{*}$ & +1.0 \\
\hline \multirow[t]{8}{*}{1969} & 1 & 66.1 & 66.8 & 65.5 & 65.8 & -0.8 & +0.5 \\
\hline & 2 & 60.6 & 62.2 & 57.8 & 60.4 & $-2.3 * * *$ & $+2.1 * * *$ \\
\hline & 3 & 61.7 & 62.0 & 61.2 & 62.1 & -0.2 & $+0.6^{*}$ \\
\hline & 4 & 65.0 & 65.2 & 63.1 & 63.3 & $-1.9 * *$ & +0.2 \\
\hline & 5 & 62.2 & 62.3 & 60.4 & 60.9 & -1.6 & +0.3 \\
\hline & 6 & 65.5 & 66.1 & 65.6 & 65.8 & -0.1 & +0.4 \\
\hline & 7 & 65.2 & 65.5 & 64.1 & 65.4 & -0.6 & +0.8 \\
\hline & mean & 63.8 & 64.3 & 62.5 & 63.4 & $-1.1 * * *$ & $+0.7 * *$ \\
\hline \multirow[t]{3}{*}{1970} & 1 & 73.4 & 73.4 & 71.3 & 72.1 & $-1.7 * *$ & +0.4 \\
\hline & 2 & 74.7 & & 74.9 & & +0.2 & - \\
\hline & 3 & 73.1 & & 70.5 & & $-2.6^{*}$ & - \\
\hline \multicolumn{2}{|c|}{4 years, aver. $^{1}$ ) } & 66.2 & 66.9 & 64.5 & 65.3 & $-1.7^{* *}$ & $+0.8^{* *}$ \\
\hline
\end{tabular}

1) In 1970 only Farm 1 included

Table 10. Valorimeter value.

\begin{tabular}{|c|c|c|c|c|c|c|c|}
\hline \multirow{2}{*}{ Year } & \multirow{2}{*}{$\begin{array}{c}\text { Farm } \\
\text { No. }\end{array}$} & \multicolumn{2}{|c|}{ Not irrigated } & \multicolumn{2}{|c|}{ Irrigated } & \multirow{2}{*}{$\frac{\text { Irrigation }}{\text { effect }}$} & \multirow{2}{*}{$\frac{\mathrm{N} \text {-fertilization }}{\text { effect }}$} \\
\hline & & $N_{1}$ & $\mathrm{~N}_{2}$ & $\mathrm{~N}_{1}$ & $\mathrm{~N}_{2}$ & & \\
\hline 1967 & 1 & 58 & 78 & 51 & 70 & -8 & $+20 * * *$ \\
\hline 1968 & 1 & 71 & 74 & 59 & 66 & $-10^{*}$ & $+6^{*}$ \\
\hline \multirow[t]{8}{*}{1969} & 1 & 50 & 69 & 48 & 64 & -4 & $+18^{* * *}$ \\
\hline & 2 & 46 & 50 & 39 & 42 & $-8^{* * *}$ & +4 \\
\hline & 3 & 57 & 56 & 46 & 49 & $-9^{*}$ & +1 \\
\hline & 4 & 78 & 79 & 71 & 75 & -6 & +3 \\
\hline & 5 & 49 & 56 & 42 & 40 & $-12 * *$ & +3 \\
\hline & 6 & 48 & 56 & 37 & 50 & $-9^{* *}$ & $+11^{* * *}$ \\
\hline & 7 & 61 & 59 & 53 & 57 & -5 & +1 \\
\hline & mean & 55 & 61 & 48 & 54 & $-8^{* * *}$ & $+6^{* *}$ \\
\hline \multirow[t]{3}{*}{1970} & 1 & 70 & 72 & 57 & 69 & $-9^{*}$ & $+7^{*}$ \\
\hline & 2 & 64 & & 59 & & -5 & - \\
\hline & 3 & 76 & & 69 & & -7 & - \\
\hline \multicolumn{2}{|c|}{4 years, aver. $\left.{ }^{1}\right)$} & 64 & 71 & 54 & 65 & $-8^{* * *}$ & $+9^{* *}$ \\
\hline
\end{tabular}

1) In 1970 only Farm 1 included 
duction was $8 \pm 3$ units (from 68 to 60 ). This reduction was fully compenstated by the additional nitrogen fertilization, which increased the valorimeter value on an average by $9 \pm 6$ units (from 59 to 68 ).

Table 11. Pelshenke value, min.

\begin{tabular}{|c|c|c|c|c|c|c|c|}
\hline \multirow{2}{*}{ Year } & \multirow{2}{*}{$\begin{array}{c}\text { Farm } \\
\text { No. }\end{array}$} & \multicolumn{2}{|c|}{ Not irrigated } & \multicolumn{2}{|c|}{ Irrigated } & \multirow{2}{*}{$\frac{\text { Irrigation }}{\text { effect }}$} & \multirow{2}{*}{$\frac{\mathrm{N} \text {-fertilization }}{\text { effect }}$} \\
\hline & & $\mathrm{N}_{1}$ & $\mathrm{~N}_{2}$ & $\mathrm{~N}_{1}$ & $\mathrm{~N}_{2}$ & & \\
\hline 1967 & 1 & 91 & 93 & 108 & 107 & $+16^{* *}$ & +1 \\
\hline 1968 & 1 & 90 & 83 & 80 & 82 & -6 & -3 \\
\hline \multirow[t]{8}{*}{1969} & 1 & 85 & 120 & 86 & 139 & $+10^{*}$ & $+44^{* *}$ \\
\hline & 2 & 37 & 42 & 31 & 31 & $-9 * *$ & +3 \\
\hline & 3 & 63 & 60 & 62 & 57 & -2 & -4 \\
\hline & 4 & 100 & 109 & 94 & 97 & -9 & +6 \\
\hline & 5 & 93 & 94 & 50 & 83 & -27 & +17 \\
\hline & 6 & 51 & 80 & 39 & 65 & $-14^{*}$ & +28 \\
\hline & 7 & 76 & 78 & 73 & 77 & -2 & +3 \\
\hline & mean & 72 & 83 & 62 & 78 & -8 & $+14^{*}$ \\
\hline \multirow[t]{3}{*}{1970} & 1 & 81 & 68 & 89 & 77 & +9 & $-13^{* *}$ \\
\hline & 2 & 71 & - & 58 & - & -13 & - \\
\hline & 3 & 56 & - & 62 & - & +6 & - \\
\hline \multicolumn{2}{|c|}{4 years, aver. $^{1}$ ) } & 84 & 82 & 85 & 86 & +3 & -1 \\
\hline
\end{tabular}

1) In 1970 only Farm 1 included

Pelshenke value (Table 11)

The Pelshenke value is regarded as a rough measure of the strength of wheat. It shows the length of time elapsing before a dough ball disintegrates after it has been placed in water. The Pelshenke value depends, in addition to the protein content, particularly on the quality of the protein.

Irrigation despite decreasing the protein content, did not decrease the Pelshenke value. The effect was positive in two trials, negative in two other trials and insignificant in eight trials. This may be a proof of improvement in the protein quality caused by irrigation.

The influence of nitrogen fertilization on the Pelshenke value was in most trials also insignificant. In one trial the effect was positive, and negative in another trial. Because nitrogen fertilization improved the protein content but did not improve the Pelshenke value, this may indicate an impairment in the quality of the protein.

\section{Discussion}

When interpreting the results of this study, it should be borne in mind, that in regard to the soil, wheat variety and fertilization there were certain differences 
between the trials. In spite of the large variation caused by these factors and by the differing weather conditions in the experimental years and sites, many clear results were obtained.

The effect of irrigation on the grain yield was the best on clay soils which accords well with previous results (ELONEN et al. 1967). Compared to clay, soil moisture conditions in finesand and mould are markedly better, and therefore the need for irrigation is smaller.

The wheat harvest was carried out at a relatively early stage of ripening and under fairly good weather conditions every year. Consequently the falling numbers were high in every trial. According to OLERED (1967), the variation in the falling number between 350 and 250 or perhaps even 200 may reflect a normal ripening phenomenon and is no proof that sprouting has started.

It can be assumed that irrigation has affected the falling number in two opposite ways: 1. It decreased the falling number in the trials where it retarded ripening and where the moisture of grains at the harvest was still high (Farms No. 2, 5, 6 in 1969). The ripening, characterized by an increased condensation of starch and inactivation of $\alpha$-amylase, had not yet advanced far enough in the irrigated wheat but the primary $\alpha$-amylase activity was still high. 2 . On the other hand, the irrigated wheat stand was denser and it ripened more evenly than the unirrigated one, which had a positive effect on the falling number. This effect was clearest in 1968 when the unirrigated crops included green shoots and the detrimental late tillering could be prevented by irrigation. - In most trials the positive and negative effects of irrigation on the falling number were, however, slight or they compensated each other.

Irrigation decreased the protein content of wheat very distinctly in every trial. This unfavourable reduction may be partly caused by losses of soil and fertilizer nitrogen (KAILA and Elonen 1971). The main reason is, however, the increase in yield and its increased demand for nitrogen (ELONEN et al.

Table 12. Effects of irrigation and nitrogen fertilization on the yield and baking quality characteristics of spring wheat, averages in four experimental years.

\begin{tabular}{|c|c|c|c|c|c|c|}
\hline & \multicolumn{2}{|c|}{ Not irrigated } & \multicolumn{2}{|c|}{ Irrigated } & \multirow{2}{*}{$\frac{\text { Irrigation }}{\text { effect }}$} & \multirow{2}{*}{$\frac{\mathrm{N} \text {-fertilization }}{\text { effect }}$} \\
\hline & $\mathrm{N}_{1}$ & $\mathrm{~N}_{2}$ & $\mathrm{~N}_{1}$ & $\mathrm{~N}_{2}$ & & \\
\hline Moisture of grains at & & & i & & & \\
\hline harvest, $\%$................ & 24.5 & 26.2 & 24.2 & 26.5 & \pm 0 & $+2.0^{* *}$ \\
\hline Grain yields, $\mathrm{kg} / \mathrm{ha} . . . \ldots \ldots . .$. & 2660 & 2820 & 3710 & 4250 & $+1240 * * *$ & $+350 * *$ \\
\hline $\begin{array}{l}\text { Protein content of grains, } \\
\quad \% \text { of DM } \ldots \ldots \ldots \ldots \ldots \ldots . . . . . . . . .\end{array}$ & 15.5 & 17.2 & 13.1 & 15.1 & $-2.2 * * *$ & $+1.9 * * *$ \\
\hline Falling number, sec. ........ & 296 & 273 & 318 & 323 & $+36^{*}$ & -9 \\
\hline Zeleny values, ml. .......... & 60 & 67 & 46 & 59 & $-11 * *$ & $+10^{* *}$ \\
\hline Cold viscosity, sec. ........ & 188 & 240 & 80 & 148 & -100 & +60 \\
\hline Water absorption, $\%$....... & 66.2 & 66.9 & 64.5 & 65.3 & $-1.7 * *$ & $+0.8 * *$ \\
\hline Valorimeter value ........... & 64 & 71 & 54 & 65 & $-8 * * *$ & $+9 * *$ \\
\hline Pelshenke value, min. ..... & 84 & 82 & 85 & 86 & +3 & -1 \\
\hline Zeleny value/protein- $\% \ldots$ & 3.9 & 3.9 & 3.4 & 3.9 & -0.2 & +0.2 \\
\hline Pelshenke value/protein- $\%$ & 5.4 & 4.8 & 6.6 & 5.7 & $+1.0^{* *}$ & $-0.8^{*}$ \\
\hline
\end{tabular}


1967, Kaila and Elonen 1970, Elonen and Kara 1972). This demand can be satisfied by additional nitrogen fertilization. In the present material the demand for additional nitrogen, caused by two irrigations in June, could be almost fully satisfied by the quantity of $67 \mathrm{~kg}$ nitrogen per hectare.

It is quite natural that the baking quality characteristics that depend on the protein content were impaired by irrigation but improved by nitrogen fertilization (Table 12). In the present material, the following correlation coefficients between the protein content of grains and the baking quality characteristics were obtained.

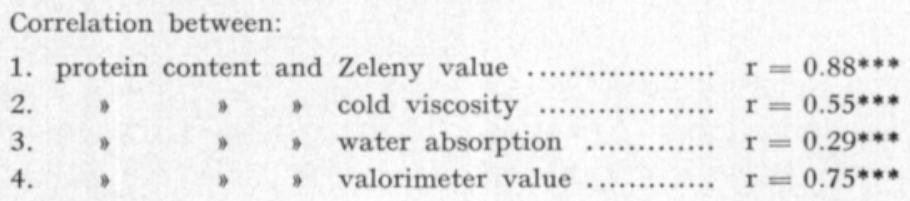

These correlation coefficients varied, however, widely in different years, particularly the cold viscosity and the water absorption:

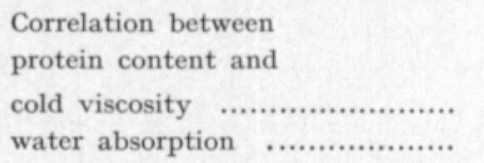

\begin{tabular}{llll}
\multicolumn{5}{c}{ Correlation coefficient } \\
1967 & 1968 & 1969 & 1970 \\
$0.82^{* * *}$ & $0.89^{* * *}$ & $0.57^{* * *}$ & $0.75 * * *$ \\
$0.74^{* * *}$ & $0.89^{* * *}$ & $0.54^{* * *}$ & -0.14
\end{tabular}

Yearly variations of the same kind have previously been reported in the studies by Suomela $(1969,1970)$ and Seibel et al. (1971).

The results of the Pelshenke test refer to the fact that irrigation improved the quality of protein, because the ratio of the Pelshenke value per protein content was significantly increased by irrigation (Table 12). The effect of nitrogen fertilization was, again, reversed. This result accords well with previous study which indicates that irrigation impairs the protein content but improves the amino acid composition of spring wheat (ELONEN et al. 1972).

Accordingly, irrigation and nitrogen fertilization affected the quantity and quality of protein and the baking quality characteristics of spring wheat in opposite directions but the quantity of grain yield in the same direction. When the two methods were combined, it was possible to produce $60 \%$ higher grain yields (from 2660 to $4250 \mathrm{~kg} / \mathrm{ha}$, Table 12) without any noteworthy changes in the protein content or in the baking quality characteristics.

Proper nitrogen fertilization is therefore a very important factor in connection with irrigation. Abundant nitrogen includes, however, two risk factors: 1. a risk of lodging and 2. a risk of retardation of ripening. The higher nitrogen level of this study, $143 \mathrm{~kg}$ nitrogen per hectare, was fairly suitable in the good weather conditions of the experimental years but it may prove too high in rainy years. Therefore, the authors recommend an amount of about $120 \mathrm{~kg}$ nitrogen per hectare for fertilization of spring wheat on clay soils in southern Finland. According to the present study, this quantity of nitrogen in connection with irrigation may result in fairly good grain yields with protein contents of about $14 \%$ level and with relatively good baking quality characteristics. 


\title{
REFERENCES
}

Bilinski, E. \& McConnel, W. B. 1958. Studies on wheat plants using carbon-14 compounds. VI. Some observations on protein biosynthesis. Cer. Chem. 35:66-81.

Elonen, P., Aно, L. \& Korvistornen, P. 1972. Influence of irrigation and nitrogen fertilization on the amino acid composition of spring wheat. J. Scient. Agric. Soc. Finl. 44: 5662.

- $-\&$ KARA, O. 1972. Sprinkler irrigation of clay soils in southern Finland. IV. The effect of repeated application of water and nitrogen fertilization on spring cereals. J. Scient. Agric. Soc. Finl. 44: 149-163.

- - , Nieminen, L. \& Kara, O. 1967. Sprinkler irrigation on clay soils in southern Finland. II. Effect on the grain yield of spring cereals. J. Scient. Agric. Soc. Finl. 39: 78-89.

FAjersson, F. 1961. Nitrogen fertilization and wheat quality. Agri Hortique Gen. 9: 1-195. Landskrona.

- - 1974. Climate, fertilisation, variety - essential factors for wheat quality. Phosphorus in Agric. 28: 49-59.

НцулкA, I. 1964. Wheat, chemistry and technology. 603 p. St Paul, Minnesota.

Hoseney, R. C., Finney, K. F., Shogren, M. D. \& Pomeranz, Y. 1969. Functional (breadmaking) and biochemical properties of wheat flour components III. Characterization of gluten protein fractions obtained by ultracentrifugation. Cer. Chem. 46: 126-135.

KAILA, A. \& Elonen, P. 1970. Influence of irrigation and supply of available nitrogen on growth and nutrient content of spring wheat. J. Scient. Agric. Soc. Finl. 42: 205-215.

- - \& Elonen, P. 1971. Effect of irrigation on fertilization nitrogen in arable clay soil. Acta Agr. Fenn. 123: 126-135.

OleRED, R. 1967. Development of $\boldsymbol{\alpha}$-amylase and falling number in wheat and rye during ripening. 106 p. Uppsala.

Pomeranz, Y. 1973. From wheat to bread: A biochemical study. Amer. Scient. 61: 683-691.

Serbel, W., Drews, E. \& Rermers, H. 1971. Sortenabhängigkeit von Qualitätsmerkmalen beim Roggen. Z. Pfl.züchtung 66: 130-150.

Standard Methoden für Getreide, Mehl und Brot. 1971. Arbeitsgemeinschaft Getreideforschung. 138 p. Detmold.

SuomelA, H. 1969. Ein einfaches Verfahren zur Weizenklassifizierung im Getreidehandel. Mühle 106: 468-469.

- -1970 . Klassifizierung des Weizens im Getreidehandel. 18. NCF-Kongress i Helsinki, Kongressberättelse 1969: 62-70. Helsinki.

\section{SElostus}

\section{Sadetuksen ja typpilannoituksen vaikutus kevätvehnän satoon ja eräisiin leivontaominaisuuksiin}

\author{
Paavo Elonen ${ }^{1}$ ) ja Sirkka-Liisa Rinne \\ Maatalouden tutkimuskcskus, maantutkimuslaitos, 01301 Vaniaa \\ Hilkka SuOMel.a ${ }^{2}$ ) \\ Yliopiston kasvinviljelytieteen laitos, 00710 Helsinki
}

Vuosina 1967-70 Yliopiston maanviljelyskemian laitos ja Maatalouskoneiden tutkimuslaitos järjestivät yhteistutkimuksena 12 kevätvehnän sadetuskoetta seitsemälle maatilalle Uudellemaalle, Hämeeseen, Varsinais-Suomeen ja Satakuntaan. Näiden kokeiden vehnänäytteet analysoitiin Viljantutkimustoimikunnan laboratoriossa.

1) Aikaisempi toimipaikka: Yliopiston maanviljelyskemian laitos, Viikki

${ }^{2}$ ) Aikaisempi toimipaikka: Viljantutkimustoimikunnan ja Valtion viljavaraston tutkimuslaboratorio. 
Sadetus, joka suoritettiin kahdesti $30 \mathrm{~mm}: \mathrm{n}$ vesimäärällä kesäkuussa, lisäsi vehnäsatoja keskimäärin $1240 \pm 470 \mathrm{~kg} /$ ha (2740 kilosta 3980 kiloon) eli $45 \pm 17 \%$. Sadonlisäykset olivat merkitseviä savimailla (9 koetta) ja hiuemaalla (1 koe), mutta hienohietamaalla (1 koe) ja multamaalla (1 koe) sadetuksesta ei saatu tilastollisesti varmaa sadonlisäystä.

Toisena koetekijänä oli typpilannoitus. Alemmalla lannoitustasolla käytettiin typpeä keskimäärin $76 \mathrm{~kg}$, korkeammalla $143 \mathrm{~kg} / \mathrm{ha}$. Runsaammalla typpilannoituksella saatiin keskimäärin $350 \pm 200 \mathrm{~kg} /$ ha eli $11 \pm 6 \%$ runsaampia vehnäsatoja. Sadettamatta typpilannoituksen lisääminen lisäsi satoja keskimäärin vain $150 * \mathrm{~kg} / \mathrm{ha}$, mutta sadettaen $540 * * * \mathrm{~kg} / \mathrm{ha}$.

Sadetus edisti vehnän tuleentumista merkitsevästi yhtenä koevuotena, mutta hidasti tuleentumista lievästi kolmena muuna koevuotena. Lisätyppilannoitus hidasti lievästi tuleentumista jokaisena vuonna.

Vehnăn sakoluku, joka edullisten korjuusäiden ja suhteellisen aikaisen puinnin ansiosta oli jokaisessa kokeessa erittäin hyvä, parani keskimäärin sadetuksen vaikutuksesta (sadettamatta 285, sadetettuna 321). Useimmissa kokeissa sadetuksella sen paremmin kuin lisätyppilannoituksellakaan ei kuitenkaan ollut merkitsevää vaikutusta vehnän sakolukuun.

Sadetus alensi vehnän valkuaispitoisuutta jokaisessa 12:ssa kokeessa. Keskimäärin valkuaispitoisuus aleni $2.2 \pm 0.7 \%$-yksikköä (sadettamatta $16.3 \%$, sadetettuna $14.1 \%$ ). Sadetuksen aiheuttama valkuaispitoisuuden aleneminen voitiin kuitenkin lähes täysin estää lisätyppilannoituksella, joka puolestaan säännöllisesti kohotti valkuaispitoisuuksia, keskimäärin $1.9 \pm 0.4$ \%-yksikköä (14.3:sta 16.2:een).

Useiden vehnän leipoutuvuutta kuvaavien tunnuslukujen arvo riippuu valkuaispitoisuudesta. Tästä syystä on luonnollista, että sadetus alensi Zeleny-lukua (64 ml sadettamatta, 53 sadetettuna), kylmäviskositeettia (214 sekunttia sadettamatta, 114 sadetettuna), jauhojen vedensitomiskykyä (66.5\% sadettamatta, 64.9 sadetettuna) ja valorimetrilukua (68 sadettamatta, 60 sadetettuna). Typpilannoitus päinvastoin paransi näitä tunnuslukuja.

Vehnän kestoluku (Pelshenke-luku), joka riippuu paitsi valkuaispitoisuudesta myös sitkon laadusta, ei sen sijaan heikentynyt sadetuksen vaikutuksesta. Tästä voitiin päätellä sadetetun vehnän sitkon olevan laadultaan parempaa kuin sadettamattoman.

Yhteenvetona voitiin todeta, että sadetus ja typpilannoitus vaikuttivat vehnän valkuaispitoisuuteen ja useimpiin leivontaominaisuuksiin vastakkaisilla tavoilla mutta jyväsadon määrään samansuuntaisesti, satoa lisäten. Sadettamalla ja runsaammalla typpilannoituksella voitiin siten saada keskimäärin $60 \%$ parempia vehnäsatoja, joiden valkuaispitoisuus ja leivontaominaisuudet pysyivät likimain samoina kuin sadettamatta ja pienempiä typpimääriä käyttäen.

Lisäksi todettiin, että vaikka runsas typpimäärä, $143 \mathrm{~kg} / \mathrm{ha}$, näytti oikeaan osuneelta koevuosina, niin pahoina sadekesinä näin runsas typpilannoitus vie vahvakortisenkin vehnän lakoon. Tästä syystä suositellaan sadetettavan vehnäpellon lannoitukseen Etelä-Suomen savialueella käytettäväksi typpeä noin $120 \mathrm{~kg} / \mathrm{ha}$. Tällä typpilannoituksella voidaan valkuaispitoisuus sadetuksesta huolimatta pitää noin $14 \%:$ n tasolla, jolloin myös leipoutuvuusominaisuudet ovat melko hyvät. 